\title{
Uji Antikanker dan Antioksidan Ekstrak Metanol Daun Pasote (Dysphania ambrosioides L.) Anticancer and Antioxidant Test of Pasote (Dysphania ambrosioides L.) Leaves Methanol Extract
}

\author{
Praise Frena Maningkas ${ }^{1 *}$ ), Dingse Pandiangan ${ }^{1)}$, Febby Ester Fany Kandou ${ }^{1)}$ \\ Jurusan Biologi, FMIPA, UNSRAT, Manado \\ ${ }^{\star} E$-mail: praisefrena@gmail.com
}

Diterima 10 Juli 2019, diterima untuk dipublikasi 10 Agustus 2019

\begin{abstract}
Abstrak
Uji antikanker dan antioksidan ekstrak metanol daun Pasote (Dysphania ambrosioides L.) telah dilakukan. Tujuan penelitian ini adalah untuk mendapatkan informasi ilmiah mengenai potensi antikanker dan antioksidan ektrak metanol serbuk daun Pasote. Pengujian antikanker dilakukan dengan metoda uji MTT pada sel leukemia P388.Uji antioksidan dilakukan dengan metode DPPH dan ditentukan dengan Spektro UV-Vis pada panjang gelombang $517 \mathrm{~nm}$. Hasil pengamatan dan pengukuran diuji dengan program Origin Lab untuk antikanker, dan program Excel untuk analisis data antioksidan. Ekstak metanol Pasote memiliki aktivitas antikanker kategori kuat sebagai antikanker dengan $I C_{50}$ sebesar $53,37 \mu \mathrm{g} / \mathrm{mL}$. Hasil pengujian antioksidan ekstrak metanol daun Pasote termasuk kategori kuat dengan nilai $I_{50}$ sebesar $50,131 \mu \mathrm{g} / \mathrm{mL}$. $\mathrm{Hal}$ ini menunjukkan bahwa ektrak metanol daun Pasote potensial untuk dijadikan antioksidan dan tidak berbeda nyata dengan antioksidan vitamin $C$. Kesimpulannya bahwa ektrak metanol daun Pasote potensial untuk dijadikan antikanker dan antioksidan.
\end{abstract}

Kata Kunci: Antikanker; Antioksidan; Leukemia P388; MTT assay; DPPH

\begin{abstract}
Anticancer and antioxidant test of Pasote (Dysphania ambrosioides L.) leaf methanol extract have been done. The purpose of this study was to obtain scientific information about the potential anticancer and antioxidant of Pasote methanol leaf extract. Anticancer testing was carried out by the MTT assay method on P388 leukemia cells. The antioxidant test was carried out using the DPPH method and determined by UV-Vis spectra at a wavelength of $517 \mathrm{~nm}$. The results of observations and measurements were tested with the Origin Lab program for anticancer, and the Excel program for analysis of antioxidant data. The methanol Pasote extract has a strong anticancer activity as an anticancer with $I C_{50}$ value $53.37 \mu \mathrm{g} / \mathrm{mL}$. The results of the antioxidant test of the Pasote leaf methanol extract included a strong category with $I C_{50}$ values $50,131 \mu \mathrm{g} / \mathrm{mL}$. This shows that Pasote leaf methanol extract is potential to be used as an antioxidant and not significantly different from antioxidant vitamin $C$. In conclusion, Pasote leaf methanol extract is potential to be used as an anticancer and antioxidant.
\end{abstract}

Keywords: Anti-cancer; Anti-oxida; Leukemia P388; MTT assay; DPPH 


\section{PENDAHULUAN}

Indonesia merupakan
negara
yang dikenal $\begin{array}{r}\text { dengan } \\ \text { keanekaragaman hayati yang } \\ \text { terbesar di dunia (Sampurno 2009). } \\ \text { Indonesia memiliki kawasan hutan } \\ \text { tropis terkaya kedua di dunia setelah } \\ \text { Brazil dan disebut juga sebagai } \\ \text { kawasan mega- } \\ \text { biodiversitas (Pandiangan 2011). }\end{array}$

Masih banyak kekayaan alam berupa tumbuhan obat yang belum dikelola dengan baik (Sampurno 2009). Salah satu contoh kekayaan keanekaragaman jenis tumbuhan obat yaitu tumbuhan Pasote (Dysphania ambrosioides L.) Indonesia khususnya Sulawesi Utara tumbuhan ini sering disebut dengan Pasote atau Sambote. Penelitian yang telah dilakukan oleh Ghareeb et al. (2016), menyatakan genus ini mengandung adanya flavonoid, terpen, seskuiterpen pigmol, xilosida, kumarin, dan minyak esensial. Aktivitas biologis yang ditunjukkan dari tumbuhan Pasote seperti antimikroba, sitotoksisitas, antioksidan, larvisida, antidiabetes, antiparasit, antivirus, dan moluskidal (Ghareeb et al. 2016).

Senyawa antioksidan secara alami pada obat obat herbal sangat dibutuhkan. Antioksidan merupakan suatu senyawa yang dapat menghambat atau menunda oksidasi suatu molekul dengan cara mengakhiri reaksi berantai inisiasi dan penyebarannya (Molyneux 2004). Manfaat antioksidan yaitu, melindungi tubuh dari berbagai penyakit seperti degeneratif, kanker, serta membantu menekan proses penuaan (Tapan 2005).

Pengujian antioksidan yang sering digunakan adalah metode DPPH (1,1dyphenil-2-picrylhydrazyl). Metode ini merupakan metode yang cepat, sederhana dan tidak memerlukan biaya yang banyak (Zou et al. 2004). Mengetahui adanya potensi tumbuhan sebagai antioksidan dapat dihitung menggunakan parameter $\mathrm{IC}_{50}$
(Winarno 2011).

Penelitian antikanker menjadi perhatian dan prioritas para peneliti Farmasi. Antikanker merupakan obat untuk mencegah dan mengobati pertumbuhan sel-sel jaringan tubuh yang tidak normal, sedangkan kanker merupakan penyakit yang disebabkan oleh pertumbuhan sel-sel jaringan tubuh yang tidak normal (Hafil, 2016). Sekarang ini telah banyak masyarakat yang memanfaatkan tumbuhan obat tradisional sebagai obat antikanker. Tumbuhan yang digunakan sebagai obat, hanya berdasarkan pengalaman masyarakat sehari-hari.

Uji antikanker yang banyak dilakukan adalah menggunakan mencit (in vivo) yang relatif lama dan keberhasilannya rendah. Tetapi, sekarang telah ada teknik kultur sel (in vitro), yaitu suatu teknik untuk mengisolasi secara aseptik dalam tabung dan ditumbuhkan dalam media buatan (Pandiangan 2011). Oleh karena itu maka perlu diteliti potensi antikanker dan antioksidan ektrak methanol daun Pasote (Dysphania ambrosioides L.).

\section{METODE}

\section{Pengambilan dan Pengolahan Sampel}

Sampel diambil di daerah Langowan, Sulawesi Utara. Setelah Pasote diambil kemudian dicuci bersih, tiriskan dan diiris kecil-kecil, lalu ditimbang sebanyak satu $\mathrm{kg}$. Hasil penimbangan tersebut dinyatakan sebagai berat basah. Daun tersebut selanjutnya dikeringkan dalam oven pada suhu $45^{\circ} \mathrm{C}$ sampai beratnya konstan (berat kering). Sampel daun yang telah kering, dihaluskan menggunakan blender. Hasil blender diayak dan disaring sebanyak 2 kali sampai didapatkan serbuk halus daun Pasote. 


\section{Ekstraksi}

Ekstraksi dilakukan secara maserasi dengan merendam 100 gram serbuk halus daun Pasote dalam toples kaca dengan penambahan satu liter metanol teknis. Sampel direndam selama $7 \times 24$ jam dan setiap 6 jam dilakukan pengadukan. Hasil rendaman tersebut disaring menggunakan kertas saring whatman $43(15.0 \mathrm{~cm})$. Selanjutnya ekstrak hasil saringan diisi ke dalam cawan arloji dan diuapkan dalam suhu ruang $37^{\circ} \mathrm{C}$ sampai kering. Ekstrak metanol kering seberat $1 \mathrm{mg}$ selanjutnya digunakan untuk uji aktivitas antikanker dan $5 \mathrm{mg}$ ektrak kering untuk uji antioksidan.

\section{Uji Aktivitas Antikanker}

Pengujian antikanker diawali dengan persiapan buffer dan media serta sterilisasi dilakukan sesuai dengan yang dilakukan oleh Laboratorium Kimia Organik Bahan Alam (KOBA) ITB. Uji antikanker dilakukan dengan mengunakan sel leukemia P388. Sel dipelihara dalam botol kultur pada media RPMI (Roswell Park Memorial Institute) dalam multiwell plate. Pengkulturan sel dilakukan dalam kondisi steril. Kultur sel dipelihara sampai memenuhi $80 \%$ substrat. Subkultur dilakukan mengikuti metoda yang digunakan Alley (1988) dalam Pandiangan (2008). Kultur sel yang telah memenuhi $80 \%$ substrat diasosiasi. Diasosiasi dilakukan dengan cara pencucian kultur sel dengan FBS (Fetal Bovine Serum) sebanyak 3 kali, lalu dibilas dengan EDTA $0,02 \%$ dan diberi tripsin $0,25 \%$. Sel diinkubasi pada suhu $37^{\circ} \mathrm{C}$ dalam inkubator $\mathrm{CO}_{2}$ selama 2 menit sampai sel lepas dari substrat botol kultur. Suspensi sel ditambah dengan medium pemeliharaan yang mengandung 5\% FBS (Fetal Bovine Serum) dengan perbandingan volume 1:1. Supernatan hasil sentrifugasi dibuang dan pelet sel diberi medium pemeliharaan. Sel hidup dihitung menggunakan hemositometer tipe Improved Neubauer dengan rumus perhitungan menurut Freshney, (2000) dalam Sahid (2013).

Ekstrak metanol daun Pasote yang telah dikeringkan sebanyak satu mg ditambahkan dengan satu $\mathrm{mL}$ DMSO (Dimethyl sulfoxide) sampai larut sebagai stok larutan ekstrak untuk membuat variasi konsentrasi. Kemudian dibuat variasi konsentrasi ekstrak mulai dari 0,$1 ; 0,3 ; 1 ; 3$; 10;30 dan $100 \mu \mathrm{g} / \mathrm{mL}$. Masingmasing ekstrak dimasukkan ke kultur sel leukemia P388. Sel yang telah diberi ekstrak dipelihara pada medium dasar yang mengandung $2 \%$ FBS dan diinkubasi selama 24 jam agar sel melekat pada substrat (KOBA ITB). Aktivitas pertumbuhan sel setelah perlakuan diukur dengan pemberian larutan MTT (3-(4,5-dimetiltiazol-2-il)2,5-difeniltetrazolium bromid).

Mediumnya dibuang dan diberi $200 \mu \mathrm{L}$ medium dasar yang mengandung $2 \%$ FBS (Fetal Bovine Serum) dan $50 \mu \mathrm{L}$ larutan MTT untuk setiap sumur. Sel diberi MTT untuk mengukur efek sitotoksik sampel. Sel diinkubasi selama 4 jam pada suhu $37^{\circ} \mathrm{C}$ dengan kondisi gelap. Setelah itu, medium dibuang dan diberi 200 $\mu \mathrm{L}$ DMSO (Dimethyl sulfoxide) dan 25 $\mu \mathrm{L}$ bufer glisin. Intensitas absorbansi warna diukur dengan menggunakan microplate spectrophotometer (Bio Rad) pada panjang gelombang 540 $\mathrm{nm}$. Intensitas absorbansi warna dibuat untuk mencari nilai Inhibition concentration sebanyak 50\% $\left(\mathrm{IC}_{50}\right)$ dari ekstrak daun Pasote.Pengukuran dilakukan 3 kali dari tiap konsentrasi, masing-masing konsentrasi diulang tiga kali (KOBA ITB).

\section{Uji Aktivitas Antioksidan dengan Metode DPPH}

Penetapan $\quad \mathrm{IC}_{50}$ dari ekstrak metanol Pasote (sampel) dan vitamin C (standar) dilakukan dengan metode peredaman radikal bebas dengan menggunakan DPPH (1,1-difenil-2pikrilhidrazil) dengan spektrofotometri 
UV-Visible. Prosedur yang dilakukan dalam pengujian aktivitas antioksidan dengan metode DPPH adalah sebagai berikut:

a. Pembuatan larutan DPPH : Serbuk DPPH sebanyak $0.4 \mathrm{mg}$ dilarutkan dengan metanol $50 \mathrm{~mL}$ dalam Erlenmeyer disimpan pada suhu kamar dan terlindung dari cahaya.

b. Penempatan panjang gelombang $(\lambda)$ maksimal DPPH : Larutan DPPH $10 \mathrm{~mL}$ dipipet ke dalam labu ukur. Metanol ditambahkan hingga volumenya mencapai $100 \mathrm{~mL}$. Homogenkan dan dibiarkan selama 30 menit lalu diukur serapannya pada panjang gelombang 400-800 nm menggunakan spektrofotometri UV- Visibel dan diperoleh panjang gelombang maksimum DPPH yaitu $517 \mathrm{~nm}$.

c. Pengukuran aktivitas antioksidan Vit.C: Penelitian ini sebagai standar yaitu, vitamin C (Ascorbic acid) $100 \mathrm{mg}$ dalam $2 \mathrm{~mL}$. Vitamin $\mathrm{C}$ dilarutkan dengan metanol sampai volumenya $50 \mathrm{~mL}$ diperoleh larutan stok dengan konsentrasi 1000 ppm. Dibuat bebrapa volume yaitu 0,$1 ; 0,2 ; 0,4$ dan $0,8 \mathrm{~mL}$ dimasukkan ke dalam labu ukur. Selanjutnya ditambahkan $1 \mathrm{~mL}$ DPPH ke dalam labu ukur yang berisi vitamin $\mathrm{C}$. Metanol ditambahkan sampai volumenya mencapai $5 \mathrm{~mL}$ dikocok dan didiamkan selama 30 menit pada suhu kamar. Masing-masing larutan tersebut diukur serapannya pada panjang gelombang $517 \mathrm{~nm}$, dilakukan sebanyak 3 Ulangan.

\section{Pengukuran aktivitas antioksidan Pasote}

Ekstrak Pasote ditimbang sebanyak $50 \mathrm{mg}$ lalu dilarutkan dengan metanol sebanyak $50 \mathrm{~mL}$ diperoleh larutan stok dengan konsentrasi $1000 \mathrm{mg} / \mathrm{mL}$. Pipet sebanyak $0,1,0,2,0,4$ dan $0,8 \mathrm{~mL}$ dimasukkan ke dalam labu ukur.
Selanjutnya diambahkan $1 \mathrm{~mL}$ DPPH ke dalam labu ukur yang berisi ekstrak ditambahkan metanol sampai volumenya mencapai $5 \mathrm{~mL}$. Larutan dikocok hingga homogen dan didiamkan selama 30 menit pada suhu kamar lalu diukur serapannya pada panjang gelombang $517 \mathrm{~nm}$, dilakukan sebanyak tiga kali Ulangan (Suhaling 2010).

\section{Analisis Data}

Potensi aktivitas antikanker dan antioksidan ekstrak metanol daun Pasote dapat diketahui dengan melakukan uji $\quad \mathrm{IC}_{50}$ (Inhibition Concentration 50\%) melalui persamaan logaritma. Analisis data uji potensi antikanker menggunakan aplikasi Originlab 9.0 32-bit (Originlab Corporation USA) dan antioksidan menggunakan aplikasi Excel.

\section{HASIL DAN PEMBAHASAN Hasil Ekstraksi}

Hasil penentuan kadar air simplisia daun Pasote diperoleh berat segar sebanyak 800 gram, dan diperoleh berat kering 112,98 gram dengan kadar airnya 85,8\% (Gambar 1). Kadar air daun Pasote cukup besar.

Sampel serbuk halus direndam dengan metanol agar dinding sel daun Pasote akan terlarut dalam pelarut yang digunakan (Haryadi 2012). Sampel daun yang direndam dengan metanol diuapkan menghasilkan ekstrak sebanyak 25,61 gram. Hasil yang didapat pada penelitian ini berupa ekstrak kasar, dengan nilai rendemen yaitu 3,2\%. Rendemen adalah perbandingan antara ekstrak yang diperoleh dengan simplisia awal (Abdillah 2006). Hasil ekstraksi selanjutnya diuji antikanker secara in vitro dan antioksidan. 


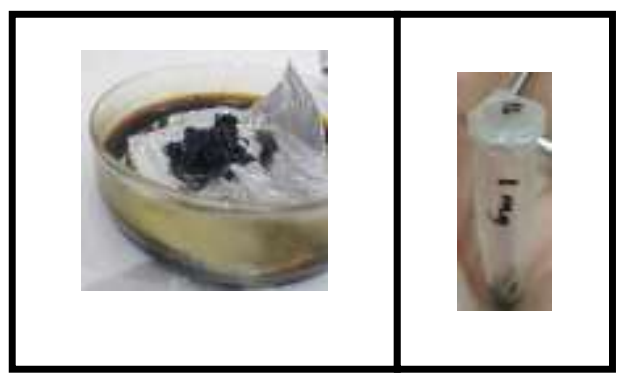

(a)

(b)

Gambar 1. Hasil ekstraksi secara maserasi menggunakan metanol: (a) ekstrak kasar untuk pengujian aktivitas antioksidan, (b) ekstrak kering untuk pengujian antikanker.

\section{Pengujian antioksidan}

Pengujian antioksidan diawali dengan menimbang dan membuat larutan stok $\mathrm{DPPH}$, vitamin $\mathrm{C}$ dan sampel yang digunakan, masingmasing didapat larutatan stok sebanyak $50 \mathrm{~mL}$. Panjang gelombang serapan maksimum ditentukan menggunakan larutan kontrol yaitu metanol. Panjang gelombang maksimum yang didapat yaitu $517 \mathrm{~nm}$ dengan nilai absorbansi kontrol ekstrak metanol Pasote yaitu 0,612. Pengujian antioksidan vitamin $\mathrm{C}$ diperoleh nilai absorbansi kontrol yaitu 0,650. Ekstrak metanol Pasote terdapat empat konsentrasi yaitu: 20, 38, 74 dan $138 \mu \mathrm{g} / \mathrm{mL}$. Mencari konsentrasi Pasote didapat dari konsentrasi Vitamin $C$ dimana menggunakan rumus $\mathrm{V} 1 \times \mathrm{C} 1=\mathrm{V} 2 \mathrm{x}$ C2. Setiap konsentrasi dilakukan tiga kali ulangan, semakin besar konsentrasi maka semakin kecil pula nilai absorbansinya (Tabel 1).

Hasil pengujian antioksidan ekstrak metanol daun Pasote pada setiap konsentrasi terjadi perubahan warna secara bertahap dari warna ungu berubah menjadi kuning. Perubahan warna ungu menjadi kuning pada uji aktivitas antioksidan menandakan terjadinya penghambatan aktivitas radikal bebas sebanyak 50 persen. Interaksi antioksidan dengan DPPH baik transfer elektron atau radikal hidrogen pada DPPH, akan menetralkan karakter radikal bebas dari DPPH dan membentuk DPPH tereduksi. Jika semua elektron pada radikal bebas DPPH menjadi berpasangan, maka warna larutan berubah dari ungu tua menjadi kuning terang dan absorbansi pada panjang gelombang $517 \mathrm{~nm}$ akan hilang (Rohman et al. 2010). Penelitian ini menggunakan vitamin $\mathrm{C}$ cair $100 \mathrm{mg} / 2 \mathrm{~mL}$ sebagai senyawa pembanding. Vitamin C merupakan antioksidan yang larut dalam air. Penggunaan vitamin $C$ sebagai pembanding pada pengujian aktivitas antioksidan ini adalah untuk mengetahui seberapa kuat potensi antioksidan yang ada pada ekstrak metanol daun Pasote jika dibandingkan dengan vitamin $\mathrm{C}$.

Dari hasil perhitungan didapat nilai $I C_{50}$ ekstrak metanol Pasote adalah $50,131 \mu \mathrm{g} / \mathrm{mL}$ termasuk kategori kuat sebagai antioksidan, untuk nilai $I_{50}$ vitamin C 48,552 $\mu \mathrm{g} / \mathrm{mL}$ termasuk kategori sangat kuat karena $<50$ $\mu \mathrm{g} / \mathrm{mL}$. Penelitian Sebelumnya dari Agustikawati et al. (2017), uji aktivitas antioksidan dan penapisan fitokimia dari ekstrak daun pokoasi dan kluwih sebagai sumber antioksidan alami dengan nilai $I C_{50}$ vitamin $C$ sebesar $46,74 \mu \mathrm{g} / \mathrm{mL}$ dan nilai $I C_{50}$ ekstrak daun pokoasi dan kluwih berturut-turut $89,659 \mu \mathrm{g} / \mathrm{mL}$ dan $54,719 \mu \mathrm{g} / \mathrm{mL}$ dimana vitamin $\mathrm{C}$ yang digunakan memiliki aktivitas antioksidan lebih tinggi dibandingkan dengan ekstrak. Hasil penelitian ini dapat dilihat dari hasil $I C_{50}$ daun Pasote aktif dan berpotensi sebagai antioksidan, dari nilai $I C_{50}$ dimanaa tingkat kekuatan antioksidan senyawa termasuk sangat kuat jika $I C_{50}<50 \mu \mathrm{g} / \mathrm{mL}$, kuat $I C_{50}$ $50-100 \mu \mathrm{g} / \mathrm{mL}$, sedang $I C_{50} 101-150$ $\mu \mathrm{g} / \mathrm{mL}$, lemah $I C_{50}>150 \mu \mathrm{g} / \mathrm{mL}$. Semakin kecil nilai $I C_{50}$ semakin tinggi aktivitas antioksidannya (Ariyanto 2006). Penyebab aktivitas antioksidan 
ekstrak metanol Pasote lebih rendah dari vitamin $\mathrm{C}$ konsentrasi yang digunakan masih terlalu besar dan masih dalam ekstrak metanol Pasote dalam bentuk ekstrak tidak murni.

Tabel 1. Hasil pengukuran nilai absorbansi, persen inhibisi ekstrak metanol daun Pasote (Dysphania ambrosioides L.) dan persamaan regresi linear menggunakan Excel

\begin{tabular}{lcccc}
\hline Ekstrak & $\begin{array}{c}\text { Konsentrasi } \\
(\boldsymbol{\mu g} / \mathbf{m L})\end{array}$ & $\begin{array}{c}\text { Nilai } \\
\text { Absorbansi }\end{array}$ & $\begin{array}{c}\% \\
\text { Inhibisi }\end{array}$ & $\begin{array}{c}\text { Persamaan } \\
\text { regresi linear }\end{array}$ \\
\hline Kontrol & 0 & 0,612 & 0 & 0 \\
\hline Ulangan 1 & 20 & 0,071 & 49,598 & $\mathrm{Y}=0.0218 \mathrm{X}+$ \\
& 38 & 0,071 & 49,598 & 48.906 \\
& 74 & 0,067 & 50,252 & $\mathrm{R}^{2}=0.9569$ \\
& 138 & 0,056 & 52,049 & \\
\hline Ulangan 2 & 20 & 0,073 & 49,108 & $\mathrm{Y}=0.0167 \mathrm{X}+$ \\
& 38 & 0,067 & 50,252 & 49.164 \\
& 74 & 0,066 & 50,415 & $\mathrm{R}^{2}=0.8623$ \\
& 138 & 0,060 & 51,396 & \\
\hline Ulangan 3 & 20 & 0,080 & 48.128 & \\
& 38 & 0,061 & 50.579 & $\mathrm{Y}=0.0261 \mathrm{X}$ \\
& 74 & 0,065 & 51.232 & +48.691 \\
& 138 & 0,057 & 51.886 & $\mathrm{R}^{2}=0.6885$ \\
\hline
\end{tabular}

Tabel 2. Hasil pengukuran nilai absorbansi dan \% inhibisi vitamin C ekstrak metanol daun Pasote (Dysphania ambrosioides L.)

\begin{tabular}{lcccc}
\hline Ekstrak & $\begin{array}{l}\text { Konsentrasi } \\
(\mu \mathrm{g} / \mathbf{m L})\end{array}$ & $\begin{array}{c}\text { Nilai } \\
\text { Absorbansi }\end{array}$ & $\begin{array}{c}\% \\
\text { Inhibisi }\end{array}$ & $\begin{array}{c}\text { Persamaan } \\
\text { regresi linear }\end{array}$ \\
\hline Kontrol & 0 & 0,650 & 0 & 0 \\
\hline Ulangan 1 & 20 & 0,102 & 49,308 & $\mathrm{Y}=0,0349 \mathrm{X}+$ \\
& 38 & 0,099 & 49,769 & 48,297 \\
& 74 & 0,097 & 50,077 & $\mathrm{R}^{2}=0,9182$ \\
& 138 & 0,075 & 53,462 & \\
\hline Ulangan 2 & 20 & 0,103 & 49,154 & $\mathrm{Y}=0,0347 \mathrm{X}+$ \\
& 3 & 0,099 & 49,769 & 48,309 \\
& 8 & & & $\mathrm{R}^{2}=0,9676$ \\
& 7 & 0,095 & 50,385 & \\
\hline Ulangan 3 & 4 & 0,076 & 53,308 & \\
& 138 & 0,102 & 49,308 & \\
& 2 & 0,099 & 49,769 & $\mathrm{Y}=0,0337 \mathrm{X}+$ \\
& 0 & 0,096 & 50,231 & $\mathrm{R}^{2}=0,9423$ \\
& 7 & & & \\
\hline
\end{tabular}


Tabel 3. Hasil $I C_{50}$ ekstrak metanol daun Pasote dan vitamin $\mathrm{C}$ ekstrak metanol daun Pasote (Dysphania ambrosioides L.)

\begin{tabular}{cccc}
\hline \multicolumn{4}{c}{ Ekstrak Metanol Daun Pasote } \\
\hline Replikasi & $I C_{50}(\mu \mathrm{g} / \mathrm{mL})$ & $\overline{\mathrm{X}}(\mu \mathrm{g} / \mathrm{mL})$ & $\overline{\mathrm{X}} \pm S D$ \\
\hline 1 & 50,183 & & \\
2 & 50,153 & 50,131 & $50,131 \pm 0,064$ \\
3 & 50,059 & & \\
\hline \multicolumn{4}{c}{ Vitamin $\mathrm{C}$} \\
\hline Replikasi & $I C_{50}(\mu \mathrm{g} / \mathrm{mL})$ & $\overline{\mathrm{X}}(\mu \mathrm{g} / \mathrm{mL})$ & $\overline{\mathrm{X}} \pm S D$ \\
\hline 1 & 48,796 & 48,552 & $48,552 \pm 0,300$ \\
2 & 48,731 & &
\end{tabular}

\section{Pengujian Antikanker}

Penelitian ini menggunakan sel kanker leukemia (P388) yang dapat digunakan dalam penelitian untuk mengetahui toksisitas suatu ekstrak terhadap sel kanker leukemia secara in vitro. Pengujian antikanker menggunakan metode MTT (3-(4,5dimetiltiazol-2-il)-2,5-difeniltetrazolium bromid) yang berwarna ungu. Pengujian antikanker memiliki enam konsentrasi 100, 30, 10, 3, 1 dan 0,3 $\mu \mathrm{g} / \mathrm{mL}$.

Hasil pengujian ekstrak metanol Pasote pada penelitian ini diperoleh nilai $I C_{50}$ nya adalah $53,37 \mu \mathrm{g} / \mathrm{mL}$ (Gambar 2). Pembanding yang digunakan adalah senyawa aktif antikanker Quersetin dengan nilai $I C_{50}$ sebesar $87,78 \mu \mathrm{g} / \mathrm{mL}$. Hasil pengujian tersebut termasuk kategori potensial atau kuat, hal itu dikarenakan $I C_{50}$ $<100 \mu \mathrm{g} / \mathrm{mL}$. Hasil tersebut menunjukkan bahwa ekstrak metanol daun Pasote memiliki potensi kuat sebagai antikanker (Prayong, 2008).

Hasil penelitian yang telah dilakukan oleh Ghareeb et al. (2016), menyatakan bahwa tumbuhan Pasote mengandung senyawa metabolit sekunder berupa flavonoid, terpen, sesquiterpen pigmol, xilosida,kumarin, dan minyak esensial. Kemampuan atau potensi antikanker tersebut kemungkinan juga akibat adanya senyawa metabolit sekunder yang dihasilkan oleh tumbuhan itu sendiri (Pandiangan, 2009).

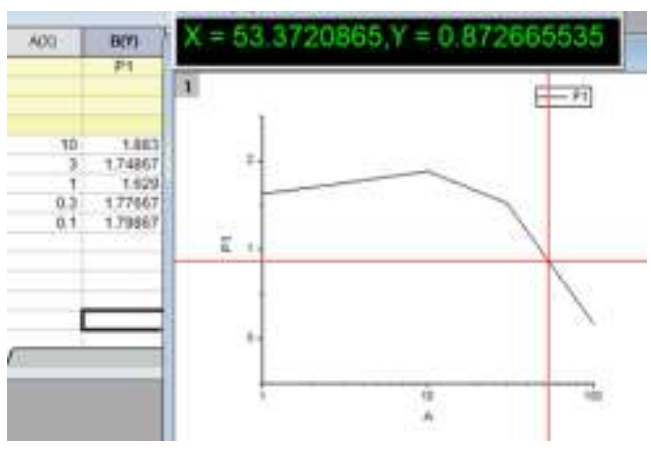

Gambar 2. Grafik persamaan logaritma antara rata-rata absorbansi dengan konsentrasi ekstrak dalam menentukan nilai $I C_{50}$ ekstrak metanol daun Pasote (Dysphania ambrosioides L.) terhadap sel leukemia P388 sebesar 53,37 menggunakan aplikasi Originlab 9.0 32bit.

Penelitian Ngama et al (2015), menunjukkan bahwa nilai $I C_{50}$ dari ekstrak metanol $P$. vittata diperoleh sebesar $82,81 \mu \mathrm{g} / \mathrm{mL}$. Hasil penelitian ektrak metanol daun Pasote lebih potensial sebagai antikanker. Sitotoksisitas suatu ekstrak berdasarkan nilai $I C_{50}$ digolongkan menjadi 3 yaitu: sitotoksisitas potensial $\left(I C_{50}<100 \mu \mathrm{g} / \mathrm{L}\right)$, sitotoksisitas sedang $\left(/ C_{50}<1000\right.$ $\mu \mathrm{g} / \mathrm{L})$ dan rendah $\left(/ C_{50}>1000 \mu \mathrm{g} / \mathrm{L}\right)$ (Prayong, 2008). Oleh sebab itu ekstrak metanol daun Pasote 
potensial untuk dijadikan antikanker.

\section{KESIMPULAN}

Ekstak metanol daun Pasote $(D$. ambrosioides) memiliki nilai $I_{50}$ sebesar 50,131 $\mathrm{\mu g} / \mathrm{mL}$ dengan metode DPPH yang berpotensi kuat sebagai antioksidan. Hasil uji aktivitas antikanker P388 dengan metode MTT Assay diperoleh $I C_{50}$ sebesar $53,37 \mu \mathrm{g} / \mathrm{mL}$ berpotensi kuat sebagai antikanker.

\section{DAFTAR PUSTAKA}

Abdillah A (2006) Aktivitas Antipolirasi Ekstrak Air Daun Sisik Naga (Pyrrosia nummularifolia (Sw.) Ching) terhadap Sel Lestari Tumor HeLa secara In vitro [skripsi]. Fakultas Kedokteran Hewan IPB, Bogor.

Agustikawati N, Andayani Y, dan Suhendra D (2017) Uji Aktivitas Antioksidan dan Penapisan Fitokimia dari Ekstrak Daun Pokoasi dan Kluwih Sebagai Sumber Antioksidan Alami. JPPIPA 3(2): 60-67.

Ariyanto R (2006) Uji Aktivitas antioksidan, Penentuan Kandungan Fenolik dan Flavonoid Total Fraksi Kloroform dan Fraksi Air Ekstrak Metanolik Pegagan (Centella asiatica L. Urban). Yogyakarta: Fakultas Farmasi Universitas Gadjah Mada (tidak dipublikasikan).

Freshney RI (2000) Culture of Animal Cells : A Manual of Basic Technique, 4th ed. Willey-Liss Inc, Canada.

Ghareeb MA, Saad AM, Abdou AM, Refahy LAG, and Ahmed WSA (2016) New Kaempferol Glycoside with Antioxidan Activity from Chenopodium ambrosioides Growing in Egypt. Orient J Chem 32(6): 3054-3061.

Hafil (2016) Farmakologi (Anti Kanker).http://darknessthe.blogs pot.com/2012/01/farmakologianti- kanker.html [17 Oktober 2018].

Haryadi D (2012) Senyawa Fitokimia dan Sitotoksisitas Ekstrak Daun Surian (Toona sinensis) terhadap Sel Vero dan MCF-7 [skripsi]. Fakultas Matematika dan IImu Pengetahuan IPB, Bogor.

Molyneux P (2004) The Use Of The Stable Free Radical Diphenylpicrylhydrazyl (DPPH) for Estimating Antioxidant Activity. Songklanakarin Journal of Science and Technology 26(2): 211- 219.

Pandiangan $D$, Esyanti $R$, dan de Queljoe E (2008). Aktivitas Antikanker Katarantin pada Sel Mouse Mammary Cancer MmT06054. Jurnal IImiah Sains 8(1): 107-113.

Pandiangan D (2011) Produksi Katarantin Melalui Kultur Jaringan. Lubuk Agung, Bandung.

Prayong J, Barusrux S, and Weerapreeyakul N (2008) Cytotoxcic Activity Screening of ssome Indigenous Thai plants. Fitoterapia 79(7): 598-601.

Rohman A, Riyanto S, Yuniarti N, Saputra WR, Utami R, and Mulatsih W (2010) Antioxidant Activity, Total Phenolic and Total Flavaonoid of Extracts and Fractions of Red Fruit (Padanus conoideus Lam). International Food Research Journal 17: 97 106.

Sampurno H (2009) Prospek Pengembangan Obat Herbal Indonesia, Pergumulan Kompleks Bagi Kesehatan Rakyat. PT. Combiphar Jakarta.

Suhaling S (2010) Uji Aktivita Antioksidan Ekstrak Metanol Kacang Merah (Phaseolus vulgaris L.) dengan Metode DPPH [Skripsi]. Fakultas IImu Kesehatan. Universitas Islam 
Negeri Alauddin, Makassar.

Tapan E (2005) Kanker, Antioksidan, dan Terapi Komplementer. Jakarta: PT Gramedia.

Winarno E (2011) Uji Sitotoksik Ekstra Kapang Aspergillus sp. terhadap Sel Kanker Payudara T47D [Skripsi]. Program Studi Biologi Fakultas Matematika
Dan Ilmu Pengetahuan Alam. Universitas Indonesia (UI), Depok.

Zou Y, Lu Y, and Wei D, (2004) Antioxidant Activity of a Flavonoid-Rich Extract of Hypericum perforatum L. in Vitro. J. Agric. Food Chem 52(16): 5032-5039. 